\title{
Correction to: Homelessness, emergency care and mental health. Inner-city emergency department psychiatry referrals: a retrospective descriptive analysis
}

\author{
Aoibheann McLoughlin ${ }^{1}$ (I) $\cdot$ Anna Feeney ${ }^{1} \cdot$ John Cooney $^{2}$ \\ Published online: 12 October 2020 \\ (C) Royal Academy of Medicine in Ireland 2020
}

Correction to: Irish Journal of Medical Science (2020) https://doi.org/10.1007/s11845-020-02392-3

This article was published online with incorrect spelling of author name. Author Anna's surname was spelt incorrectlyit should be Feeney rather than 'Feeny'. The original article has been corrected.

Publisher's note Springer Nature remains neutral with regard to jurisdictional claims in published maps and institutional affiliations.

The online version of the original article can be found at https://doi.org/ $10.1007 / \mathrm{s} 11845-020-02392-3$

\footnotetext{
Aoibheann McLoughlin

aoibheannmcloughlin@gmail.com

1 Psychiatry Registrar, St. Patrick's Hospital, Dublin 8, Ireland

2 St. James's Hospital, Dublin 8, Ireland
} 